knowing that the end for which he has striven so worthily has been achieved; it is the task of his successors in office to see that the full weight of scientific knowledge is brought to bear on all the manifold problems, both in peace and war, with which the rulers of Great Britain are confronted.

\section{The Universities' Debt to Greece}

THE Vice-Chancellor of the University of Cambridge presided at a public meeting held in the Regent House on November 23 to support the cause of Greece in the War. He was accompanied by the Greek Minister, the Provost of King's College (Mr. J. T. Sheppard), Sir Frederick Maurice (principal of Queen Mary College, London), the regius professor of Greek (Prof. D. S. Robertson), the Lord Lieutenant (Mr. C. R. W. Adeane) and the Mayor of Cambridge (Mr. E. O. Brown). The Vice-Chancellor (Mr. E. A. Benians, master of St. John's College) spoke of the sympathy and regard with which Greece is regarded in Great Britain, and particularly in the ancient universities of the country. "Wherever universities exist," he said, "they live and work in a light first kindled on the soil of Greece. To that source they trace the freedom of mind and spirit, without which they cannot fulfil their true functions."

H E. the Greek Minister also addressed the meeting, which passed a resolution, put by Mr. Sheppard, in the following terms: "We, Cambridge residents meeting under the chairmanship of our Vice-Chancellor, being conscious of the inestimable debt which every civilized nation owes to Greece, salute in her the source and pattern of our own free institutions, teacher of wisdom from of old, and faithful mother still of arts and sciences. Mindful also of the special ties which bind the University of Byron to the living memory of Greek heroes, we desire to place on record our profound and grateful admiration for the magnificent loyalty and courage with which the Greeks, who have so often withstood alien invaders, have dared again to take up the challenge in order to preserve for the Greek nation its own hard-won independence and to secure for the future of mankind that spiritual freedom which the world first learnt from Greece." The resolution concluded by asking the Greek Minister "to convey to friends in Greece, particularly to the members of the University of Athens, this token of our loyal friendship, of our faith in final victory and of our pride that the British Commonwealth of Nations strives and will strive with Greece for the same cause."

\section{La France Libre}

In France, in common with the other Germanoccupied countries, there is no longer any freedom of expression, which is the essential fundamental of true art, literature and science, and all that contributed to the high place which that country held in the world of learning is now suppressed. A few of the French intellectuals have escaped and on them will depend the carrying on of the torch of French culture and learning. In order to do this a monthly journal has been founded entitled La France Libre in which the records of work and expression of free thought of these exiles from France will be conserved. By this means free French learning and free French thought will be co-ordinated and kept in being until that time when France is restored to her former freedom and prestige; and indeed it can only be through efforts such as this, and of other intellectual exiles from the oppressed countries, that the individual science and culture of the nations of Europe will survive.

The journal has the support of leading British men of science and of letters, headed by Sir William Bragg, past-president of the Royal Society, and expressions of sympathy have been received from members of universities and learned institutions all over the British Isles, Canada and the United States. The first number, which was published on November 15, contains an article on "La Communauté universelle de la Science" by Sir Richard Gregory and twelve others covering a wide sphere of interest. The journal is addressed to all Frenchmen and all those who love France, and is deserving of every support. It is not to contain propaganda. The price is $2 s$. a number or one guinea a year; all particulars may be obtained from La France Libre, I5 Queensberry Place, London, S.W.7.

\section{Social Progress}

IN a paper "What is Social Progress ?" contributed to a symposium on social progress in the Proceedings of the American Academy of Arts and Sciences (73, 457-472; 1940) Prof. L. J. Henderson points out that terms like justice and social progress are useless for clear thinking because they have no accepted fairly clear meaning and can only be given an arbitrary definition at the cost of strong persistent emotional opposition. Social change, however, is a fact, but there is no logical or scientific test of the desirability of social changes except in relation to an end or purpose for which the test is utility. Prof. Henderson suggests that, in a given place, at a given time, for a given end, there may be an optimum rate of change of a given thing and some day this will be a subject ripe for careful study. The conditioned reflexes of men, as they are at any given time and in any given place, will be seldom negligible. More often than not, when the end is survival they will be again, as they have so often been, in the forms we name loyalty, the bonds of family, the sense of kinship, love of country and religious devotion, powerful social forces, and dangerously lacking when in default. Prof. Henderson suggests that among the innumerable effects of science on society, some must be harmful, according to any definition, now or hereafter, to many individuals and to some societies. Moreover, the effects of science upon society may well be only implicit functions of the state of science, but explicit functions of the rate of scientific development. The same scientific development proceeding rapidly may have one effect, proceeding slowly another quite different effect.

A second paper in the symposium, by Crane Brinton, points out that not only the word 'progress' but also almost every important word we try to use in per- 
forming logical operations on problems in the social sciences is subject to limitations, if less extreme, through lack of precise meaning. Mr. Brinton, reviewing the various meanings which progress has borne, refers first to the sense of improvement in a process or technique. Then there is the sense derived from theories of organic evolution developed in the last century or so, and finally the sense of moral or social progress. He points out that so long as the notion of progress is closely associated with our immediate notions of the difference between what is and what ought to be, progress will probably remain one of the most important ethical abstractions in common use. In a third paper, Prof. E. B. Wilson suggests that no scientific meaning can be attached to such a term as social progress until social science has advanced considerably further as a science, and social studies are unlikely to become scientific so long as the mores of our social scientists place brilliancy so far ahead of patience and generalities so far ahead of specification. We need a handbook of the social sciences which tells us what is true under what restrictive conditions. Until such coherent growth has begun and gained considerable momentum we shall probably not have the background on which to say what is social progress, and when social science has thus advanced we shall be talking rather in terms of various sorts of social progress and social retrogression.

\section{The City and South London Railway}

ON November 11 the City and South London Railway celebrated its jubilee. The one outstanding criticism of this railway which could have been made was that the designers of the new line built for conditions then existing, and failed to take into account the changes that would occur in a few years' time. For example, the tunnel diameter was much too small, so were the first locomotives, the trains and the cars. The diameter had to be increased in 1922, and extensions were made for the railway between Stockwell and King William Street. It would appear that the railway made too timid a beginning. The Electrical Times, which also began its career about fifty years ago as Lightning, has referred to its earlier criticisms of the railway, and points out that perhaps its promoters dared not venture too far on what, after all, was an experiment without precedent ; for the City and South London was the first electric tube railway ever built.

The new rolling stock has been designed to obtain the maximum amount of seating capacity consistent with comfort, and also allows a very much greater standing space than the old rolling stock. It has not been possible to introduce the new stock gradually, as part of the improvement of this railway is the moving of the conductor rail from its original position centrally between the running rails to the standard position laid down by the Ministry of Transport, namely, 16 in. outside the running rail ; $6,445 \mathrm{yd}$. of new conductor rail have been laid. In order to reduce noise to a minimum, the running rails have been welded into 315 - ft. lengths, involving 544 welded joints. Noise-absorbing shields are also being experimented with. These shields are fitted between the lower portion of the coaches and the tunnel walls. The City and South London is London's shortest tube railway. It is only 1 mile 46 chains long, and forms part of the quickest route from the heavily populated south-western suburbs to the very heart of the City. The journey only takes five minutes. The line was opened in August 1898, and carries an average of 30,000 passengers daily, most of them during the business rush hours. Nearly 40,000 yards of cables and wires have been laid in the course of the improvements.

\section{Fitting Schoolboys for the World of Work}

"Gumance Programs for Rural High Schools", by Mr. Paul Chapman (Washington, D.C. 10 cents), is a bulletin belonging to the 'Occupational and Guidance Service' established by the U.S. Office of Education in response to a widespread demand. It has been revised after critical comment on a limited. edition and shows once more the great elaboration of American education. High schools in rural districts have comparatively few pupils ; but, as the foreword points out, they are important for society as a whole, because "no large city in our Nation is producing enough children to maintain its population". Local conditions impose differences of training and the two models noticed in detail from New York State are much larger than the average rural school. But one of them is described as "basically agricultural" and both can supply selections of things worth doing. All schools of the sort can go in for "occupational information, the personal inventory, counselling, exploration, use of training facilities, placement, and follow-up". This last word means close attention to pupils after they have left school.

To keep all these activities going lays a heavy burden on teachers. At Nyack School "counselors" have a great deal to do. They interview employers and make a monthly report. Personal data are supplied concerning pupils seeking work; former students have a two-page questionnaire sent to them; and their employers are expected to say how they are getting on. It is evident that this wide vigilance must produce good results and reduce the number of misfits who are "everything by starts, and nothing long". If all teachers did anything like as much, they might steady those restless adolescents who do little good for themselves or anybody else and often end on the dole. The programmes offered go right to the root of unemployment, but they demand a good deal of time and patience.

\section{Ferns of Wales}

INTEREST in the British native flora and in the study of botany in general is so admirably stimulated and encouraged by the excellent series of exhibits in the National Museum of Wales that the descriptive handbook of Welsh ferns by Mr. H. A. Hyde, keeper of botany, and Mr. A. E. Wade, assistant in the Department, is assured of a wide welcome (Welsh Ferns : a Descriptive Handbook. By H. A. Hyde and A. E. Wade. Pp. $\mathbf{x}+132+11$ plates. Cardiff: 